\title{
Insurance in the National Accounts: A Case-Study of France
}

\author{
by Mrs. Lutgart Van den Berghe*
}

National Accounting (N.A.) may be defined as: "une méthode d'enregistrement macro-comptable d'ensembles de grandeurs caractéristiques de l'univers économique d'une société donnée (ici la Nation) pendant une période donnée ".1

There are considerable differences between systems in different countries. In order to eliminate these discrepancies international organizations have tried to set up normalized systems. The french N.A. system has been predominantly influenced by the systems of the United Nations (1968) and of the E.E.C. (1970).

Before analyzing the treatment of insurance in the new accounting System of France (SECN) ${ }^{2}$, we will give an overview of its treatment in the UNO System (UNOS) and in the EEC System (EECS).

\section{Insurance In the U.N. System}

In the last revision of the U.N. standardised system of National Accounting (SNA) two different types of accounts are distinguished;

a) the goods and services account where the national production is determined for the following economic activities :

- industries,

- producers of government services,

- producers of private non-profit services to households,

- domestic services of households,

- consumption function ;

b) the revenues and capital accounts which are set up for the following sectors :

- societies and quasi-societies, subdivided into financial and non-financial sector and into private and public subsector,

- government,

- private, non-profit organisations,

* Research fellow, University of Ghent, Seminar of Applied Economics.

$1 \mathrm{~J}$. Benard: "Comptabilité Nationale et modèles de politique économique", P.U.F., Paris, 1972, p. 14.

2 SECN $=$ "Système Elargi de Comptabilité Nationale". 
- households,

- foreign sector.

In the goods and services accounts no financial services are distinguished. It is only in the revenues and capital accounts that a distinction is made between financial and non-financial enterprises.

Insurance companies come in the sub-sector of financial companies, together with banks and credit institutes. Insurance companies are defined as : "incorporated, mutual, and other entities which mainly engage in providing life, accident, sickness, fire, casualty and other forms of insurance" 3 .

Also included are pension funds :

"Pension funds included here are separately organised schemes ... to relate to specific groups of employees and is not to be part of social security scheme" 3 .

The added value produced by the insurance sector in a given period is calculated separately for life insurance and non-life insurance activities and for pension funds. The output is called the "Gross Value of Services Rendered" or renumeration of the insurance service $(R S)$ and is calculated as follows :

For non-life insurance : $R S=P_{b}-P_{n}$

where $\boldsymbol{P}_{b}=$ premiums received,

and $\quad P_{n}=$ net premiums or risk premiums, which are assimilated to the claims paid.

The $R S$ calculated in this way differs considerably from the actual renumeration because it covers also the variation of the technical reserves and the differences between calculated risks and the risks run.

Despite these discrepancies, UN advises :

“... it is not suggested that the gross output realized on casualty insurance be equated to the normal service charge... The national experience required to know whether countries would find it practicable to correct the estimates of the service charge for either deviation from the ideal measure has not been accumulated" 4 .

For life insurances : $R S=P_{b}-P_{n}-\left(\Delta R M-I_{a}\right)$

where $P_{b}$ and $P_{n}$ are as above,

and $\Delta R M=$ variation of the mathematical reserve, and

$I_{a}=$ interest arising on the mathematical reserves and allocated to the insured.

In the opinion of the $\mathrm{UN}$, this $\left(\Delta R M-I_{a}\right)$ cannot be calculated in all cases, and so they propose to assess this variation as follows :

$\Delta R M \sim$ variation of life insurance funds which contain the actuarial reserves and the contingency reserves 5 , and

$I_{a} \sim$ interest received on life insurance funds.

3 "U.N. Yearbook of National Accounts Statistics", New York, 1970, p. 78-79.

4 ibid., p. 98.

${ }^{5} \triangle R M$ is therefore assimilated to the variation of the sum of the premium reserves (actuarial reserves) and undistributed interest. 
In the case of pension funds, $R S=$ administrative expenses.

The input is equal to the intermediate consumption - i.e., the purchases of goods and services of the insurance companies with other companies. The difference between this input and output gives the gross added value at market prices $\left(G V A_{m p}\right)$.

The primary distribution of the $G V A_{m p}$ consists of :

$Y_{h}=$ renumeration of salaried employees,

$T_{i}=$ indirect taxes,

$D=$ amortizations,

$S_{1}{ }^{\circ}=$ working balance.

The secondary distribution of the $S_{1}{ }^{\circ}$ gives :

$T_{j}=$ direct taxes,

$\left(P_{a}-S_{d}\right)_{\text {IARD }}$ gives the balance of claims due (or $\left.S_{d}\right)$ on the acquired net premiums, but the accounts give only $\left(P_{r}-P_{n}\right)$,

$Y_{c i}, Y_{c r}=$ interest and net rents,

$Y_{c o}=$ net dividends, and

$S_{2}{ }^{\circ}=$ savings.

In the consumption flow, the $R S$ is considered either as intermediate consumption or as final consumption, according as the premiums paid are the responsibility of industries or households.

\section{Assessment}

UN has endeavoured to draft a scheme for calculating the added value of the insurance sector, but with only rudimentary success. The method of assessing variations of the various kinds of reserve is particularly unsatisfactory. These variations are not even taken into consideration in calculating the V.A., while for income distribution a definition is suggested but not applied.

The definitions are not always clear, as the following example will show:

$$
R S=P_{b}-P_{n} \quad \text { and } P_{n}=P_{b}-R S
$$

The explanatory element $P_{n}$ is defined only by derivation from the actual definition.

The added value of the insurance sector is not calculated separately in the SNA nor in the flows of goods and services (since there is no production account for the different branches of the economy) nor in the income flows (since an overall account is calculated for all financial institutions together). Nor is the assessment of reinsurance activities theoretically taken into consideration.

\section{Insurance in the EECS}

Insurance companies have a specific and detailed assessment in the EECS. This sector of the economy (S.50) contains institutional units providing mainly an insurance function - i.e. converting individual risks into collective risks and, as a rule, forming

N.B. - I.A.R.D. $=$ non-life insurance. 
technical reserves. Their main resources are contractual premiums. The following are therefore excluded from this sector:

- Social insurances : the reason being that the premiums to be paid are determined irrespective of the individual risk; bodies of this kind are classified in the state sector whereas public companies engaged in insurance as previously described come under sector S.50;

- Commission agents : the reason being that their main function is purely that of intermediaries. Depending on ther legal constitution, they come into either the nonfinancial enterprise sector or into the household sector.

The V.A. of the insurance sector is calculated just for all companies and branches together and no breakdown is made. Reinsurance activities have to be classified in the overall picture in accordance with the risk accepted. Whereas the SNA calculates only received premiums and charges paid, the EECS assesses the actual charge of the insurance, starting from received premiums and benefits due. To calculate the actual charge, it is necessary to make the following estimations :

where :

$$
\begin{gathered}
P_{b}=P_{n}+R S \\
P_{n}=S_{1}+S_{2}+\left(\Delta R_{m}-I_{a}\right)+\Delta R_{b}
\end{gathered}
$$

$\boldsymbol{P}_{b}=$ gross premium received (premiums received + variation of premium reserves).

$\boldsymbol{P}_{n}=$ net or clear premium,

$R S=$ renumeration of insurance service,

$S_{1}=$ charges paid + variation of reserves for claims to be settled,

$S_{2} \quad=$ supplementary profit-linked benefits,

$I_{a}=$ actuarial interest,

$\Delta R_{m}=$ variation of mathematical reserve,

$\Delta R_{b}=$ variation of reserve for participation in profit.

The pure or risk premium was assumed for the purposes of this calculation to be equal to the charges paid or suffered.

$$
\left.\begin{array}{l}
R S=P_{b}-\left[S_{1}+S_{2}+\left(\Delta R_{m}-I_{a}\right)+\Delta R_{b}\right] \\
P_{n}=P_{r}=P_{b}-\left[R S+\left(\Delta R_{m}-I_{a}\right)+\Delta R_{b}\right]
\end{array}\right\} \quad \longrightarrow \quad P_{r}=S_{1}+S_{2}
$$

This linear equality is a simplification of the true state of affairs, where a triangular situation can be distinguished:

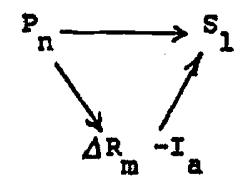

$\left(G_{i}=\right.$ interest gains allocated to the insured)

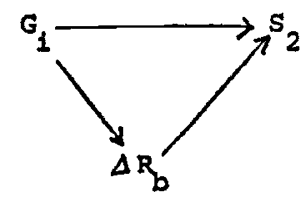


The other constituents are assessed as follows :

- The interests placed to commitments (or the actuarial interest $I_{a}$ ) are determined in the case of profit-making companies at a fixed percentage of the technical reserves, whereas in the case of non-profit-making insurers the total of unfixed incomes is taken into consideration;

- Capital gains are alloted to the insured in dependence upon the profit made;

- The output of the insurance sector is made up of the sum of the renumerations of the insurance services $(R S)$ and of fixed incomes.

\section{Assessment}

The EEC has produced a good analysis of the insurance production. UN rather neglected technical reserves in its assessment of insurance production, but the EECS carefully analyses variations of technical reserves and includes such variations in its calculations of production. Moreover the definitions given are very clear and explanatory. However, the fact that all companies and branches are included as a whole in the system makes it anything but easy to calculate production, nor is any light shed on the assessment of insurance activities. As compared with the UNOS, where the payment of claims, etc., is always accounted for via the insured, the EECS distinguishes in its disbursements those which are alloted to beneficiaries and those which are alloted to the insured. The flows of disbursements are recorded directly in the EECS system but only indirectly in the UNOS.

\section{Insurance in the French "Système élargi de comptabllité nationale" (SECN)}

The new french system of national accounts has been established in 1976 along the lines of the UNOS and EECS (see scheme 1).

It includes two subsets :

- the central framework, with detailed accounts of the various sectors of the french economy. The production concept has been enlarged to the credit institutions, insurance companies and administrations ;

- the subsystems have been established in order to describe specific activities. They gather information about particular agents (specially non-financial enterprises and insurance companies).

We shall first consider the assessment of the insurance sector at macro-economic level in the former system of national accounts.

This system neglected the productive role of the financial services:

"However, the French accounting system, considering that financial institutions had an intermediary rather than a productive function, did not call them 'enterprises' and treated them as final consumers, on the same basis as households and administrations. Consequently, financial institutions have no production account nor operating account, and their allocation account combines the elements which appeared in the production and operating accounts of enterprises " 6 .

6 Bénard, loc. cit., p. 179-180. 
Schema I

Comptes de flux des secteurs institutionnels

\begin{tabular}{|c|c|c|c|}
\hline \multicolumn{2}{|c|}{ Emplois } & \multicolumn{2}{|c|}{ Ressources } \\
\hline \multicolumn{2}{|c|}{$\begin{array}{l}\text { Consommation intermédiaire. } \\
\text { Valeur ajoutée brute. }\end{array}$} & \multicolumn{2}{|l|}{ Production. } \\
\hline \multicolumn{2}{|c|}{$\begin{array}{l}\text { Rémunération des salariés. } \\
\text { Impôts liés à la production (sauf TVA). } \\
\text { Excédent brut d'exploitation. }\end{array}$} & \multicolumn{2}{|c|}{$\begin{array}{l}\text { Valeur ajoutée brute. } \\
\text { Subventions d'exploitation (reçues). }\end{array}$} \\
\hline \multicolumn{2}{|c|}{$\begin{array}{l}\text { Opérations d'assurances dommages. } \\
\text { Autres transferts courants. } \\
\text { (Impôts sur le revenu, cotisations socia- } \\
\text { les, prestations sociales... versés). } \\
\text { Revenu disponible brut. }\end{array}$} & $\begin{array}{l}\text { REVENU } \\
\text { Excédent brut d'ex } \\
\text { Rémunération des } \\
\text { Impôts liés à la pro } \\
\text { tation (reçus) ly } \\
\text { çue par les Admir } \\
\text { Revenus de la pro } \\
\text { prise (intérêts, di } \\
\text { Opérations d'assura } \\
\text { Autres transferts co } \\
\text { revenu, cotisatio } \\
\text { tions sociales... }\end{array}$ & $\begin{array}{l}\text { ploitation. } \\
\text { salariés. } \\
\text { duction et à l'impor- } \\
\text { compris la TVA per- } \\
\text { histrations publiques]. } \\
\text { priété et de l'entre- } \\
\text { videndes... reçus). } \\
\text { nces dommages. } \\
\text { urants (impôts sur le } \\
\text { ns sociales, presta- } \\
\text { eçus). }\end{array}$ \\
\hline \multicolumn{2}{|l|}{$\begin{array}{l}\text { Consommation finale. } \\
\text { Epargne brute. }\end{array}$} & $\begin{array}{l}\text { ION DU REVENU } \\
\text { Revenu disponible }\end{array}$ & brut. \\
\hline \multicolumn{2}{|c|}{$\begin{array}{l}\text { Formation brute de capital fixe. } \\
\text { Variation des stocks. } \\
\text { Acquisitions nettes de terrains et d'actifs } \\
\text { incorporels. } \\
\text { Transferts en capital (versés). } \\
\text { Capacité (+) ou besoin (-) de finan- } \\
\text { cement. }\end{array}$} & \multicolumn{2}{|c|}{$\begin{array}{l}\text { Epargne brute. } \\
\text { Transferts en capital (aides à l'investis- } \\
\text { sement, impôts en capital... reçus). }\end{array}$} \\
\hline Flux nets de créances & $\begin{array}{l}\text { COMP' } \\
\text { Moyens de pai } \\
\text { Monnaie et dép } \\
\text { Bons négociabl } \\
\text { autres partici } \\
\text { Crédits. } \\
\text { Réserves techni } \\
\text { Solde des créan }\end{array}$ & $\begin{array}{l}\text { INANCIER } \\
\text { its internationaux. } \\
\text { on monétaires. } \\
\text { bligations, actions et } \\
\text { ns. } \\
\text { d'assurance. } \\
\text { t dettes. }\end{array}$ & Flux nets de dettes \\
\hline
\end{tabular}

SOURCE : système élargi de comptabilité nationale. Méthodes p. 35 
Until 1960 this sector was completely excluded from calculations of gross national product (GNP) and of national income. Starting in 1966 the insurance service was classified as a "financial service" and so was not allocated any productive function. The insurance service started to be assessed as a productive service with the application of the "SECN". This sector will benefit under the SECN from a large number of intermediate and macro-economic accounts specifically devised for the insurance sector.

\subsection{Calculation of the production of the insurance sector in the central framework}

The insurance enterprise sector covers all institutional units whose main service is to provide an insurance function consisting of converting individual into collective risks. Their main resources are contractually determined premiums or voluntary social contributions. The "hallmark" for the units in this sector (and the one distinguishing them from units of the Social Security sub-sector) is the fact that they manage "freely underwritten " contracts.

This sector ( $\mathrm{S} 50)$ consists of two sub-sectors :

- Insurance companies (S51), comprising units whose main resources are insurance premiums and which disburse compensation and benefits to the insured and to beneficiaries, with the constitution of technical provisions, and

- Mutual societies (S52), comprising units whose main resources are voluntary social contributions and which disburse social benefits to their members and do not usually form technical provisions (since they operate on a distribution basis).

The calculations for production and VA differ very considerably between these two sub-sectors. For insurance bodies the production of the insurances service is assessed as follows: Surplus of premiums received over indemnities due.

These two compenents can be defined as follows:

- For life and capitalization insurances :

$$
R S=\left(P_{b}-\Delta R_{p}\right)-\left[S_{1}+S_{2}-\left(\Delta R_{m}-I_{a}\right)-\Delta R_{b}\right]
$$

- for non-life insurances :

$$
R S=\left(P_{b}-R_{p}\right)-\left(S_{1}+S_{2}-\Delta R_{S}\right)
$$

where $R_{p}=$ premium reserves or reserves for risks in force, and

$R_{S}=$ casualty reserves or reserves for claims to be settled.

The insurance service output by mutual companies is defined here as the sum of management costs in relation to this activity - i.e., the sum of staffing and management costs.

The production of other services contains the housing service (P.81) and the auxiliary financial service 7 (P.78).

7 This is an auxiliary activity of insurance bodies, since some pension funds classified in the "Social Security Administrations" sub-sector are managed by insurance bodies which receive an offset in the form of a remuneration for services rendered. 
Intermediate consumption consists of the following elements :

- Intermediate consumption of goods and services (overheads);

- Commissions paid to insurance intermediaries (agents and brokers);

- The balance of reinsurance abroad.

The SECN describes the processing of reinsurance operations. Three categories are distinguished, but only the last two of them are considered macro-economically. There are three cases to be distinguished:

- Reciprocal reinsurance : this comprises the reinsurance service between companies whose main activity is direct insurance;

- Reinsurance with specialist French companies: the accounts of the specialist companies are consolidated with the accounts of the direct insurance companies;

- Reinsurance with the rest of the world : the balance of this reinsurance is considered as the (positive or negative) element of national insurance production.

The primary distribution of the VA shows indirect taxes, personnel remunerations and the gross operating balance. In the case of mutual aid companies, the gross operating balance is taken as nil since they are non-profit-making.

The secondary distribution of income has some specific aspects :

a) Net interests and dividends : an item which is usually negative because received interests and dividends exceed interests and dividends paid out;

b) Surplus $\left(P_{n}-S\right)_{I A R D}$ : nationally the surplus must be zero, but there may be divergencies in the economic sectors between, on the one hand, casualties received (paid) and, on the other hand, net premiums paid (received). Net premiums are distributed between the various sectors on the basis of premiums paid;

c) Transfers : recourse to Social Security (to mutual aid companies);

d) Interest alloted to commitments arising from insurance contracts; these are interests credited to the technical reserves held by the insurance bodies.

\subsection{Calculation of the output of the insurance sector in the intermediate system.}

The scope of the intermediate system corresponds virtually to sub-sector S51 comprising insurance and capitalization bodies of the central framework; the institutional units concerned are those forming the subject matter of the annual report of the insurance management, i.e. :

- Life insurance companies and the C.N.P. ;

- Capitalization companies ;

- Non-life companies.

Specialized reinsurance and COFACE operations companies enjoying a state guarantee do not come under this heading.

This system is based on accounts which are simpler than those of the central framework :

- Production and operating account; 
- Distribution and results account;

- Investment financing account.

These accounts are filled up from the totalizations of information supplied to the Insurance Managements or Board.

Production of the insurance service is defined as in the central framework (except for current transfers of the S.S. of the central framework which are included in claims). The main difference between the intermediate system and the central framework is the calculation of intermediate consumption :

- Firstly, the general costs are excluded from intermediate consumption and considered as a VA component ;

- Secondly, the reinsurance charge comprises, beside the charge for abroad, the charge with reinsurance companies of the French market.

Distribution of the working balance also differs as between the two systems.

The $P_{n}$ and the $S$ items are distributed in the case of both IARD and life insurances, but this is not the case in the central framework:

$$
\begin{array}{ll}
\text { Non-Life } & P_{n} \longleftrightarrow S+\Delta R_{S} \\
\text { Life } & P_{n} \longleftrightarrow S+\Delta R_{m}
\end{array}
$$

\section{GENERAL COMMENTS ON THE S.E.C.N.}

1) The insurance sector consists of two sub-sectors, a new feature as compared with other national and international systems. The two sub-sectors are :

a) Insurance and capitalization organizations whose main characteristics are :

- Main resources : insurance premiums,

- The insured and the beneficiaries of contracts receive compensation and benefits ;

b) Mutual companies whose characteristics are:

- Main resources : voluntary social contributions,

- Members receive social benefits,

- Operation as distributing concerns which do not usually set aside large amounts.

2) Adopting an intermediate system facilitates the passage from micro-accounting to macro-accounting. In our opinion, the specialized and complicated insurance sector needs this intermediate form of accounting.

3) As compared with supranational systems the SECN is distinguished by more clearly limited definitions. For instance, reinsurance assessment is differentiated according as the ceding or accepting firms are or are not based abroad.

4) In our view, the SECN, despite all its advantages, has a considerable shortcoming in that it takes no account of the secondary economic and social function of 
insurance. The technical provisions forming the majority of the financing of insurance bodies (our researches show that technical reserves make up $\pm 90 \%$ of the financing of insurance companies) should be invested in the best interests of the insured and of the beneficiaries of contracts. This function will now be described in connection with financial operations.

\section{Comments on assessment of the added value of the insurance sector in national and supranational systems.}

The complex technique of insurance has as its distinguishing feature a reversal of the production cycle from the viewpoint of insurance producers. The insured ask for security and pay premiums. The insurers receive premiums at a time when neither the existence nor the amount of the counterpart they will be required to provide is known. This is the reason for the existence of enormous reserves in insurance companies. These reserves should be invested in the best possible way in the interests of the insured :

"The technical provisions forming the majority of the financing of insurance organizations are considered as commitments for the insured. Insurance gives rise to savings which it is the job of insurance to invest in the best interests of the insured and contract beneficiaries" 8 .

Much of the investment income returns to the insured either directly, by way of immediate $\left(S_{2}\right)$ or delayed $\left(\Delta R_{b}\right)$ payments, or indirectly, as a reduction in premiums payable.

Premium reduction is administratively the simpler and more logical of the two systems to apply, but it suffers from a great defect, particularly technically, where premiums cease to cover technical charges. Equilibrium occurs only financially, when financial income is taken into consideration as well. In the accounts of the insurance sector the loading of the premium does not usually make it possible to cover intermediate consumption and added value. The production and operating account is then in debit. Consequently, the V.A. of the insurance sector calculated from the origin viewpoint often shows a negative value. The V.A. is in all cases inadequate to remunerate production factors.

To correct this difficulty the N.A. system suggested taking as components of insurance service output :

- The technical output or the strict remuneration of the insurance service, and

- Participation of the insured in received interests and dividends and profits.

At first sight the disadvantage disappears when this suggestion is applied. However, there still remains an anomaly in the various N.A. systems as regards assessment of the amount of financial income. A change in the proportion of income on liquid assets as compared with real property income has severe repercussions on calculations of the V.A. The reason for this inaccuracy is that only the former is considered in calculations of insurance V.A.

8 "Assurance et comptabilité nationale", Etudes et Bilans, Direction des Assurances. Service de l'information du Ministère de l'Economie des Finances, Paris, September 1973, p. 5. 
Insurance sector output account

$D$

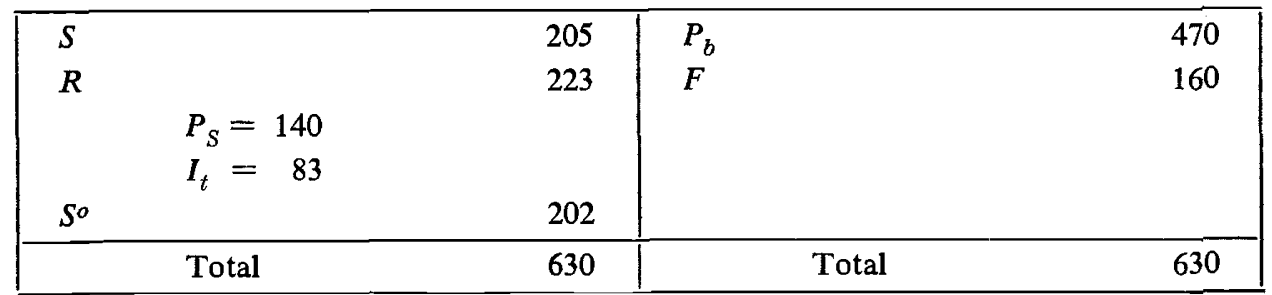

where :

$P_{b}=$ gross premiums received $=P_{S}+P_{r}+K$,

$P_{S} \quad=$ savings premium,

$P_{r}=$ risk premium,

$K=$ loading premiums,

$F=$ total of financial income $=F_{o}+F_{r}$,

$F_{o}=$ real property income,

$F_{+}=$income on liquid assets,

$S=$ disbursements due,

$\Delta R=$ variation of technical reserves $=\Delta R_{p}+\Delta R_{\mathrm{S}}+\Delta R_{m}$,

$\Delta R_{p}=$ variation of premium reserves,

$\Delta R_{S}=$ variations of casualty reserves,

$\Delta R_{m}=$ variation of mathematical reserves,

$I_{t}=$ allocated interests including capital gains distributed immediately,

$S^{o}=$ operating balance including overheads.

Table I: Calculation of insurance sector output in accordance with some assumptions

\begin{tabular}{|l|c|c|c|c|}
\hline & $F=F_{o}$ & $F=F_{r}$ & \multicolumn{2}{|c|}{$F=F_{o}+F_{r}$} \\
\cline { 3 - 5 } & & & $F_{o}=F_{r}$ & $I_{t}$ \\
\hline$P_{b}$ & 470 & 470 & 470 & 470 \\
$-\Delta R$ & 205 & 205 & 205 & 205 \\
$+I_{t}$ & 223 & 223 & 223 & 223 \\
$+F_{o}$ & 83 & 83 & 83 & 83 \\
\hline Gross output, & 160 & - & 80 & 77 \\
origin viewpoint & 285 & 125 & 205 & 202 \\
\hline Distribution & 202 & 202 & 202 & 202 \\
viewpoint $S_{o}$ & & & & \\
\hline
\end{tabular}


This Table gives rise to a wide variety of comments.

Output is overestimated when the total financial revenue consists of real property income $(285 \longleftrightarrow 202)$.

Output is underestimated when all the financial income consists of income on liquid assets $(125 \longleftrightarrow 202)$.

When financial income includes both components, output calculations are accurate provided that income on liquid assets is equal to attributed interest.

This anomaly can be removed by applying the same technique to insurance companies as to other financial institutions. The technique can be summarized as follows :

Since the output and added value of the finance sector as calculated in the previous N.A. systems always gave values which were negative or inadequate to remunerate the production factors, the new systems endeavour to overcome this snag. Banking services output was increased by the inclusion of an attributed output - i.e., remuneration for services rendered by credit institutions as financial intermediaries. This remuneration is estimated to be the difference between interest received and interest paid. This attributed output is considered, at the macroeconomic level of the N.A., as an intermediate consumption of an imaginary branch and is therefore reduced from total output.

As described in the various N.A. systems, the insurance sector experiences the same problems as the other financial services with which it is in any case always integrated. Similarly to what we stated in connection with credit institutions, we consider that the value of the insurance service should also be assessed as the difference between interests and dividends received and interests and dividends paid out. This attributed output can be assessed as follows :

$$
\begin{array}{lr}
\text { Total of income on liquid assets } & =F_{r} \\
\text { - attributed interests } & =I_{t} \\
\hline=\text { attributed output of insurance service }
\end{array}
$$

Whatever the make-up of financial income, the result of including this attributed output is that output calculated from the origin viewpoint is always equal to output calculated from the distribution viewpoint. This balance is proved in the following Table.

Insurance sector output account

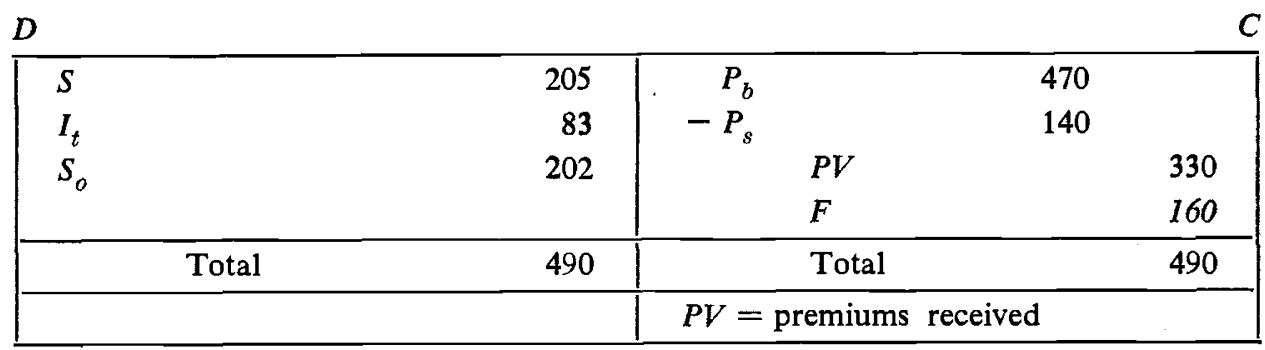


Table II : Calculation of insurance sector output in accordance with some basic assumptions

\begin{tabular}{|c|c|c|c|c|}
\hline & \multirow{2}{*}{$F=F_{o}$} & \multirow{2}{*}{$F=F_{r}$} & \multicolumn{2}{|c|}{$F=F_{o}+F_{r}$} \\
\hline & & & $F_{o}=F_{r}$ & $I_{t}$ \\
\hline Output of service & 125 & 125 & 125 & 125 \\
\hline$=\left(P_{v}-S\right)$ & $(330-205)$ & $(330-205)$ & $(330-205)$ & $(330-205)$ \\
\hline $\begin{array}{l}\text { Secondary output } \\
F_{o} \text { (housing service) }\end{array}$ & 160 & 0 & 80 & 77 \\
\hline Attributed output & -83 & 77 & -3 & 0 \\
\hline$=\left(F_{r}-I_{t}\right)$ & $(0-83)$ & $(160-83)$ & $(80-83)$ & $(83-83)$ \\
\hline $\begin{array}{l}\text { Total output } \\
\text { Origin viewpoint }\end{array}$ & 202 & 202 & 202 & 202 \\
\hline $\begin{array}{l}\text { Distribution } \\
\text { viewpoint }\end{array}$ & 202 & 202 & 202 & 202 \\
\hline
\end{tabular}

However, we want to emphasize here that attributed output must be taken into consideration when these financial income are a return on the investment of technical reserves. This restriction on attributed output also exists in the calculation of the outputs of banking services. Only income from investments of the capital of third parties is taken into consideration in calculating the attributed output of banking services.

Repercussions of this technique on the complete system

In our view, this attributed output can be integrated in the macroeconomic whole in three different ways :

1) Similarly to what is done in the banking sector, the attributed output can be assessed as the intermediate consumption of an imaginary branch ; the GNP remains the same.

2) The attributed output of the insurance service can be subdivided between the life branches (the major portion) and the non-life branches. The attributed output of the life branches must then be considered as the final consumption of households, whereas the attributed output of the non-life branches must be considered as the intermediate consumption of an imaginary branch. The G.N.P. increases by an amount equal to the attributed output of the life branches. This increase can be cut out by considering this attributed output as the intermediate consumption of households, such also having a productive function.

3) The attributed output of insurance services can be subdivided between the various economic sectors on the basis of the premiums paid thereby. The comments in Point 2) then still apply to the household sector. 


\section{Conclusion}

As proved in the previous paragraphs, it is desirable and even essential to extend the principle of attributed output to insurance services. In practice there will have to be political pressure behind any revision. Mention can be made in this context of a similar confrontation in the U.S.A.

"I would suggest that O.B.E. representatives meet with people from the Life Insurance Association of America, the Institute of Life Insurance, and possibly with a committee of economists from selected companies to discuss the problems of identifying final services, and securing the necessary data for preparing composite measures both for Life and non-Life insurance" 9 .

The inevitability of political pressure is clearly proved by the fact that a similar proposal was made 10 sometime ago in the EEC. Despite its theoretical importance, the proposal was not accepted 11 .

9 Kendrick, J.W., and Fuchs, V.R., Discussion in "Production and Productivity in Service Industries", National Bureau of Economic Research, New York, 1969, p. 47.

$10 \mathrm{OS} / 56 / 72-\mathrm{F}$.

$11 \mathrm{OS} / 53 / 73-\mathrm{F}$. 
